\title{
Process for Conducting a Cost Benefit Analysis for New Radiation Portal Monitors
}

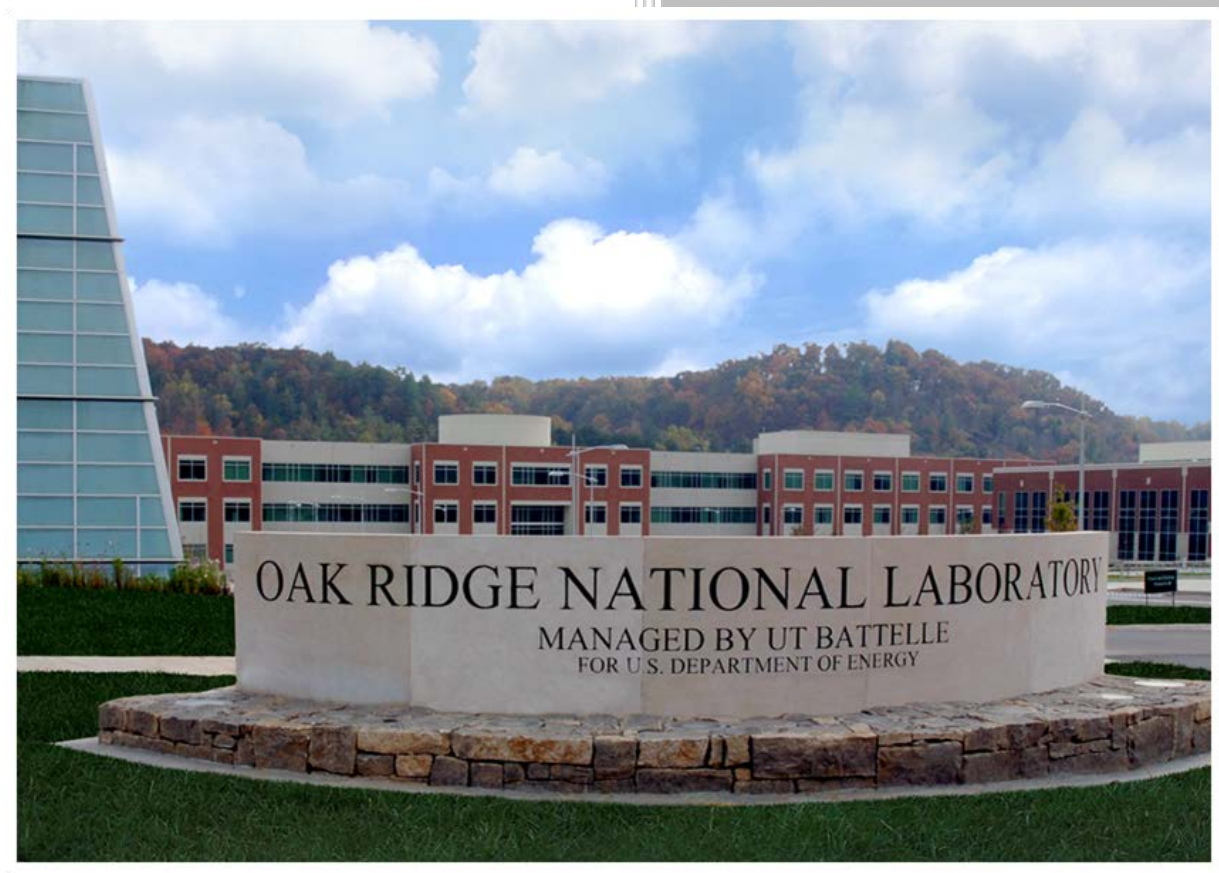

Alexander Enders Clay McAmis

January 2018

Approved for public release. Distribution is unlimited. 


\title{
DOCUMENT AVAILABILITY
}

Reports produced after January 1, 1996, are generally available free via US Department of Energy (DOE) SciTech Connect.

Website http://www.osti.gov/scitech/

Reports produced before January 1, 1996, may be purchased by members of the public from the following source:

\author{
National Technical Information Service \\ 5285 Port Royal Road \\ Springfield, VA 22161 \\ Telephone 703-605-6000 (1-800-553-6847) \\ TDD 703-487-4639 \\ Fax 703-605-6900 \\ E-mailinfo@ntis.gov \\ Website http://www.ntis.gov/help/ordermethods.aspx
}

Reports are available to DOE employees, DOE contractors, Energy Technology Data Exchange representatives, and International Nuclear Information System representatives from the following source:

Office of Scientific and Technical Information

PO Box 62

Oak Ridge, TN 37831

Telephone 865-576-8401

Fax 865-576-5728

E-mail reports@osti.gov

Website http://www.osti.gov/contact.html

This report was prepared as an account of work sponsored by an agency of the United States Government. Neither the United States Government nor any agency thereof, nor any of their employees, makes any warranty, express or implied, or assumes any legal liability or responsibility for the accuracy, completeness, or usefulness of any information, apparatus, product, or process disclosed, or represents that its use would not infringe privately owned rights. Reference herein to any specific commercial product, process, or service by trade name, trademark, manufacturer, or otherwise, does not necessarily constitute or imply its endorsement, recommendation, or favoring by the United States Government or any agency thereof. The views and opinions of authors expressed herein do not necessarily state or reflect those of the United States Government or any agency thereof. 
Nuclear Security and Isotope Technology Division

Process for Conducting a Cost Benefit Analysis for New Radiation Portal Monitors

Alexander Enders

Clay McAmis

Date Published:

January 2018

Prepared by

OAK RIDGE NATIONAL LABORATORY

Oak Ridge, TN 37831-6283

managed by

UT-BATTELLE, LLC

for the

US DEPARTMENT OF ENERGY

under contract DE-AC05-00OR22725 
(this page intentionally blank) 


\section{EXECUTIVE SUMMARY}

The Domestic Nuclear Detection Office (DNDO) has deployed over 1,400 radiation portal monitors (RPMs) around the United States to enhance border security. DNDO is now considering deployment of a newer generation of RPMs, intended to have equal or better sensitivity but a considerably lower nuisance alarm rate due to Naturally Occurring Radioactive Material (NORM) that is common in the stream of commerce. If the nuisance alarm rate is sufficiently reduced at a site, US Customs and Border Protection (CBP) may be able to reduce the staffing necessary to respond to nuisance alarms generated by the RPMs.

This document provides an overview of some possible processes for conducting a cost benefit analysis to place a reliable dollar amount on the value of these new systems. While there is no hard and fast guide for conducting a cost benefit analysis, an austere method is provided for quick estimating. Two robust methods are also provided, one taking guidance from an Office of Management and Budget circular and the other from the Government Accountability Office. 
(this page intentionally blank) 


\section{CONTENTS}

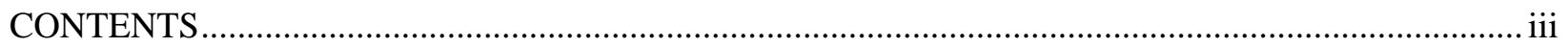

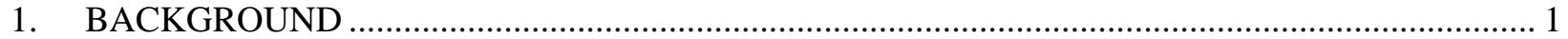

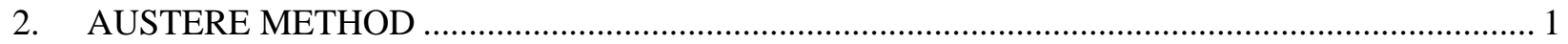

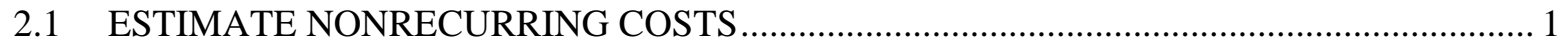

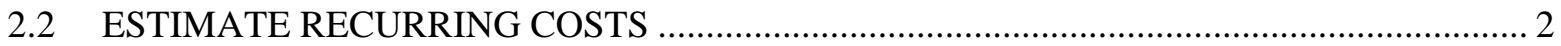

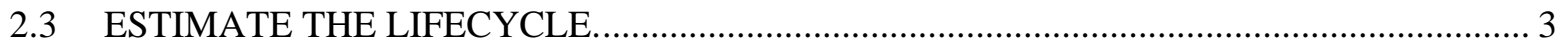

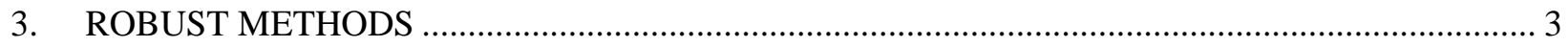

3.1 Office of Management and Budget Guidance......................................................................... 3

3.2 Government Accountability Office Guidance …................................................................... 4

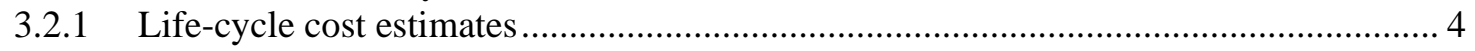

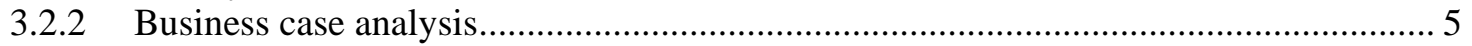

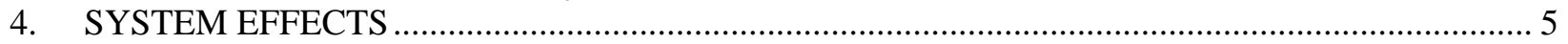

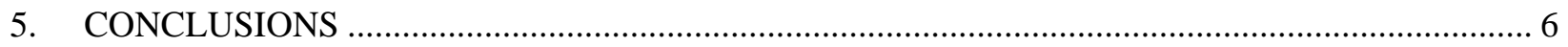

Appendix 1: A Summary of GAO reports on the Advanced Spectroscopic Portal ................................... 7 


\section{BACKGROUND}

The Domestic Nuclear Detection Office (DNDO) is considering the purchase and deployment of a new generation of radiation portal monitors (RPMs) at select US borders and seaports. These new RPMs are intended to have equivalent or better sensitivity to threat materials as the previous generation RPMs, but reduce the number of nuisance alarms that are generated from naturally occurring radioactive material (NORM). If the reduction in nuisance alarms is sufficient, it may enable US Customs and Border Protection to conduct remote operations, reducing the number of staff necessary to respond to RPM alarms, leading to a significant cost savings.

In a limited study, a few units of the next-generation RPMs (acquired through means other than the ongoing procurement) have been deployed to three sites in the United States. Preliminary estimates for those units suggest that the alarm rates have been reduced by as much as $97 \%$, ${ }^{1}$ and that remote operations can be enacted.

This report addresses the question, "What is the cost analysis process used to determine whether it is beneficial to install new RPMs at a site?" For the purposes of simplicity, development costs (i.e., those costs to test and evaluate the potential new systems) are considered sunk and are not included in the cost analysis. This document provides three methods for conducting a cost benefit analysis: an austere method and two robust methods. Note that this paper describes the methods only, not the actual product. To be viable, a method must be independently repeatable and as objective as possible. Where assumptions are made, these are specifically identified.

It would also be prudent to review the previous Government Accountability Office (GAO) reviews of DNDO's Advanced Spectroscopic Portal efforts. A summary of these publications is provided in Appendix 1.

\section{AUSTERE METHOD}

The austere method is intended as a simple, low-overhead, rapid cost benefit analysis. It provides repeatable results and a means to estimate the cost benefit, but this method does not have the rigor or extensive documentation that is associated with the robust methods.

\subsection{ESTIMATE NONRECURRING COSTS}

The first step is to estimate the nonrecurring costs, like shown in Table 1 below.

Table 1. Nonrecurring costs to be estimated for installing a new RPM.

\begin{tabular}{|l|l|l|}
\hline Cost element & Explanation & Potential source of the data \\
\hline Acquisition cost & The cost to purchase the RPM. & $\begin{array}{l}\text { This is usually specified as part of the } \\
\text { procurement process, or is included on a } \\
\text { General Services Administration } \\
\text { schedule. }\end{array}$ \\
\hline Installation cost & $\begin{array}{l}\text { The cost to install the equipment, } \\
\text { usually paid to a local electrical and/or } \\
\text { civil engineering contractor. }\end{array}$ & $\begin{array}{l}\text { The Pacific Northwest National } \\
\text { Laboratory should have historical } \\
\text { records of installation costs. }\end{array}$ \\
\hline
\end{tabular}

${ }^{1}$ Email from John Porter, Port Director of Savannah, on December 6, 2017. 


\begin{tabular}{|l|l|l|}
\hline & & $\begin{array}{l}\text { Presumably, the costs to replace an } \\
\text { existing RPM installation costs would } \\
\text { be similar (or less) than a new } \\
\text { installation. }\end{array}$ \\
\hline $\begin{array}{l}\text { Communications } \\
\text { system cost }\end{array}$ & $\begin{array}{l}\text { The cost to install any additional } \\
\text { communications hardware that may be } \\
\text { necessary for the RPM to transmit data } \\
\text { to the CBP network that is not included } \\
\text { in the acquisition cost. }\end{array}$ & $\begin{array}{l}\text { The cost for any human-machine } \\
\text { interface updates, new programmable } \\
\text { logic controllers, and new cabling that } \\
\text { may be required should be obtainable } \\
\text { from field validation tests. }\end{array}$ \\
\hline $\begin{array}{l}\text { Site } \\
\text { infrastructure } \\
\text { upgrades }\end{array}$ & $\begin{array}{l}\text { If applicable. These may include new } \\
\text { footings, additional traffic control } \\
\text { measures or barriers, or site } \\
\text { reconfiguration to support remote } \\
\text { operations. }\end{array}$ & $\begin{array}{l}\text { Some of these costs may be borne by } \\
\text { organizations external to DNDO. } \\
\text { Again, an estimate will probably be } \\
\text { obtainable as a result of the field } \\
\text { validation tests. }\end{array}$ \\
\hline Training & $\begin{array}{l}\text { Cost to train operators and users on the } \\
\text { new system. }\end{array}$ & $\begin{array}{l}\text { These costs may be small and may be } \\
\text { borne by CBP, but some training will be } \\
\text { necessary on the new systems. }\end{array}$ \\
\hline $\begin{array}{l}\text { Downstream } \\
\text { analysis } \\
\text { upgrades }\end{array}$ & $\begin{array}{l}\text { The data stream will likely be more } \\
\text { complex than the existing stream, and } \\
\text { databases will need to be updated to } \\
\text { support it. }\end{array}$ & $\begin{array}{l}\text { While the cost may not be borne by } \\
\text { DNDO, the cost to upgrade analysis } \\
\text { tools and data transfer mechanisms may } \\
\text { be significant (>\$100,000). DNDO } \\
\text { should work with downstream entities } \\
\text { (PRIDE, DAC-TER) to estimate these } \\
\text { costs. }\end{array}$ \\
\hline
\end{tabular}

The first three costs elements will apply for each RPM installed while the last three cost elements will likely apply for each site where RPMs are installed.

\subsection{ESTIMATE RECURRING COSTS}

The second step is to determine the recurring costs of operating the system.

Table 2. Recurring Costs to Operate an RPM.

\begin{tabular}{|l|l|l|}
\hline Cost element & Explanation & Potential source of the data \\
\hline Operator salary & The fully burdened rate of an operator. & $\begin{array}{l}\text { CBP has this data, and similar data has } \\
\text { been used in previous cost benefit } \\
\text { analyses. }\end{array}$ \\
\hline $\begin{array}{l}\text { Man-hours } \\
\text { needed to } \\
\text { operate }\end{array}$ & $\begin{array}{l}\text { The number of hours necessary per } \\
\text { period (week, month, or year) to } \\
\text { respond to alarms from the system. } \\
\text { between the new generation and } \\
\text { existing systems. The expectation is } \\
\text { that with a 90\% (or more) reduction in } \\
\text { hours needed to respond to alarms, the } \\
\text { new system will eventually pay for } \\
\text { itself. }\end{array}$ \\
\hline $\begin{array}{l}\text { Maintenance } \\
\text { costs }\end{array}$ & $\begin{array}{l}\text { The cost to perform both routine and } \\
\text { corrective maintenance, including } \\
\text { travel time, spare parts, and } \\
\text { maintenance training. }\end{array}$ & $\begin{array}{l}\text { RPM vendors were required to provide } \\
\text { estimates of maintenance requirements } \\
\text { as part of the solicitation; however, }\end{array}$ \\
\hline
\end{tabular}




\begin{tabular}{|l|l|l|}
\hline Electrical costs & The power draw of each system. & $\begin{array}{l}\text { these are estimates and they are likely } \\
\text { optimistic for the first few years. }\end{array}$ \\
& $\begin{array}{l}\text { The electrical requirements are likely } \\
\text { similar as existing RPMs. For an } \\
\text { example that could lead to a significant } \\
\text { increase in costs, if the new RPMs have } \\
\text { large air conditioning systems, the } \\
\text { power draw could increase. }\end{array}$ \\
\hline
\end{tabular}

\subsection{ESTIMATE THE LIFECYCLE.}

DNDO needs to consider the time frame the system is expected to be operable, and what pay-back period is acceptable. Because requirements were put in the solicitation to extend the useful life of the gamma detectors, 20 years may be a reasonable estimate for lifetime. Consequently, DNDO may determine that the cost of the new-generation RPMs should be paid back within 20 years. Costs should also be discounted appropriately to give net present value: a savings of ten dollars 20 years from now is actually a net loss if a non-zero minimum acceptable rate of return is assumed. ${ }^{2}$

\section{ROBUST METHODS}

There is no industry-standard guide with instructions to perform a cost benefit analysis. There are, however, at least two authoritative sources to reference for guidance and direction on what elements to include in such a cost benefit analysis.

\subsection{OFFICE OF MANAGEMENT AND BUDGET GUIDANCE}

In its interim report on the Advanced Spectroscopic Program (ASP) ${ }^{3}$, the National Academy of Sciences referenced the US Office of Management and Budget's (OMB) Circular A-4 (2003) ${ }^{4}$ for key elements to include in a detailed cost analysis.

Section D of the circular (Analytical Approaches) discusses both a benefit-cost analysis (BCA) and a cost-effectiveness analysis. OMB emphasizes the importance of using a cost-effectiveness analysis for "all major rulemakings for which the primary benefits are improved public health and safety to the extent that a valid effectiveness measure can be developed to represent expected health and safety outcomes." A BCA focuses on monetary units, whereas a cost-effectiveness analysis includes less tangible costs and benefits, which can be difficult to quantify. For DNDO's purposes, the OMB guidance on the BCA appears to be the most appropriate.

Section E of the circular (Identifying and Measuring Benefits and Costs) has a rough outline of a process to follow. Specifically, it requests defining the following:

- Scope of analysis

- Developing a baseline

\footnotetext{
${ }^{2}$ For example, OMB Circular A-94 recommends providing estimates using discount rates of both 3\% and 7\%.

3 "Evaluating Testing, Costs, and Benefits of Advanced Spectroscopic Portals for Screening Cargo at Ports of Entry: Interim Report,” 2009. Available at http://nap.edu/12699 . Ironically, the interim report is more substantive than the final report.

${ }^{4}$ Available at https://obamawhitehouse.archives.gov/omb/circulars_a004_a-4//.
} 
- Evaluation of alternatives

- Transparency and reproducibility of results

Section E is more devoted to less tangible studies, such as the efficacy of drug development research or wetlands reclamation. However, the section on "Treatment of Uncertainty" is particularly relevant, and the Life Cycle Cost Estimate for ASP performed by DNDO in 2010 is a stellar example of this uncertainty analysis. Commercially available tools like @Risk and Oracle’s Crystal Ball make quantitative estimates of uncertainties much more tractable.

\subsection{GOVERNMENT ACCOUNTABILITY OFFICE GUIDANCE}

In March 2009, GAO published the "GAO Cost Estimating and Assessment Guide.” This 400+ page document goes into considerable detail about many aspects of project management, including work breakdown structures, technology readiness levels, and earned value management.

The process for producing a credible cost estimate is covered in a detailed 12-step approach. To summarize this process: the purpose is defined, an estimation plan is developed, applicable rules and assumptions are identified, data is obtained, and the sensitivity analysis and uncertainty analysis are performed. The estimate is then documented, presented to management for approval, and finally updated when actual costs are incurred. The basis for this process centers around an overall estimate for a project or program; however, the same principles can be applied to procurements as well.

The importance of the cost estimate should be noted because it serves as the basis for any type of cost analysis performed. There are many methods currently in use, but GAO categorizes cost estimates into two broad categories: life-cycle cost estimates (LCCEs) and business case analyses (which the GAO refers to as a BCA, but this is a different document from the OMB BCA). When a procurement decision needs to be made on equipment such as a new radiation portal monitor, using these two techniques can lead to improved program management and better use of resources.

\subsubsection{Life-cycle cost estimates}

LCCEs are an all-inclusive approach to account for all cost elements from "cradle to grave." An organization should identify the startup costs from inception all the way through operation, maintenance and disposal. In this way, the process considers all past, present, and future costs. Once developed, this estimate serves as the baseline cost estimate for a potential procurement. The Department of Defense divides the LCCE process into four phases:

- Phase one is the research and development aspect that includes testing, evaluation, and software development.

- Phase two is the actual procurement of equipment as well as related parts, repair parts, and contractor support.

- Phase three accounts for all operations costs including manpower, maintenance, and engineering through the entire lifecycle.

- The last phase is the disposal phase, which estimates costs for final disposition.

The one downside to any life-cycle cost estimate is the fact that involvement is needed by many team members from several supporting functional areas. However, upfront work to estimate the total cost results in better program planning and improved decision making. A 2006 case study cited in the GAO guide (Chapter 4, Case Study 15) references DNDO and life-cycle costing. The study looked at the DNDO's estimate for plastic scintillators and advance spectroscopic portal monitors. DNDO's initial analysis assumed a 5-year life cycle for both items and an annual maintenance cost at $10 \%$ of the total 
procurement. What DNDO did not account for-and later realized-was that a more realistic life cycle for the monitors was 10 years. The higher maintenance costs were essentially doubled and long-term implications were magnified.

As an LCCE is being developed, it is necessary to look at affordability. Affordability is defined by the GAO as the degree to which an acquisition program's funding requirements fit within the agency's overall portfolio. Again, the cost estimate is critical but the program should also ensure that the appropriate funding is projected to be available. This plays directly into the life-cycle assessment because it can provide decision makers the data needed to address certain funding requirements at intervals in future fiscal years.

\subsubsection{Business case analysis}

The other estimate described by GAO is a cost-benefit analysis, known as a business case analysis (BCA). The GAO-defined BCA compares known facts and supporting details for competing alternatives of a procurement. GAO emphasizes that the analysis should be unbiased and fair in considering alternative solutions rather than only supporting a predetermined decision. A BCA goes one step further than a stand-alone LCCE in that it includes all relevant cost plus identifies quantifiable and nonquantifiable benefits to a decision. When performing a BCA, it is important that the team is able quantify the methods and rationale for life-cycle costs and benefits. It is also beneficial to assess risk as well as schedule and performance. Once all data is gathered and analyzed, the project team would choose the best solution. The BCA needs to be clear and concise so that an independent reviewer would understand a why an alternative was chosen.

The importance of team involvement cannot be overstated in any BCA. The personnel involved should consist of program managers, cost analysts, financial management, subject matter experts, and representatives from supporting organizations. A best practice would be to establish a centralized team who collaboratively support many programs. By having members outside of the project team, an unbiased estimate can be obtained. Often when only project team members estimate costs for procurements existing budgets play a major role and could deter a realistic cost estimate.

The GAO places an extremely high importance on cost estimation. The effort it takes to create such an estimate is rigorous and time consuming. However, it has been repeatedly proven that a comprehensive, well-defined cost estimate is the key to successful program management and key decision making. When a decision is to be made whether to purchase equipment, the cost estimation team must do its due diligence with this process. Performing a life-cycle cost estimate to analyze all expected costs from startup to closeout is crucial. Following the LCCE, the BCA is equally vital in the decision-making process because it forces a consideration of alternative options. Just as important is the makeup of the cost evaluation team which should consist of both technical and financial experts. Following this process will lead to greater success, better planning, and better use of program and tax payer dollars.

\section{SYSTEM EFFECTS}

Lastly, DNDO should consider what, if any, other elements in the radiation detection system may be impacted by the installation of the next-generation RPMs.

For example, if DNDO assumes that the new RPMs are more sensitive to threat material than the existing RPMs (this statement is purely hypothetical, but the performance improvement, if any, should be known as a result of testing), then the RPMs may alarm on cargo or sources that the secondary inspection 
equipment is unable to resolve. Although the secondary inspections will be considerably less frequent, if operators regularly perform a secondary inspection with a result of "No Isotopes Found" they will quickly lose motivation or incentive to perform a secondary inspection. Improving the capabilities of the system in primary inspection may affect the requirements of the system(s) in secondary and tertiary inspection.

As another example (alluded to above), the requirements for downstream data analysis may be affected. The new RPMs will almost certainly have a different data stream and possibly even a different alarm logic system. Either the data will have to be translated into the "old" system (which may result in relevant details being lost because of decreased fidelity) or the downstream systems will have to be modified to accept the new data formats and new information.

\section{CONCLUSIONS}

A few possible methodologies are provided herein for conducting a cost-benefit analysis, that could inform and support a decision by DNDO on whether and where to deploy the new-generation RPMs. One possible solution would be to conduct the austere method for as many sites as possible, since results are easily obtainable in a short time. If the results from that are promising, DNDO may choose to pursue one of the robust methods to make a more informed decision. 


\section{APPENDIX 1: A SUMMARY OF GAO REPORTS ON THE ADVANCED SPECTROSCOPIC PORTAL}

All of these reports are easily retrievable via an internet search of the document number.

GAO-07-133R: “Combating Nuclear Smuggling: DHS’s Cost-Benefit Analysis to Support the Purchase of New Radiation Detection Portal Monitors Was Not Based on Available Performance Data and Did Not Fully Evaluate All the Monitors’ Costs and Benefits.” October 17, 2006.

GAO-07-581T: “Combating Nuclear Smuggling: DHS’s Decision to Procure and Deploy the Next Generation of Radiation Detection Equipment Is Not Supported by its Cost-Benefit Analysis." March 14, 2007.

GAO-08-1108R: “Combating Nuclear Smuggling: DHS’s Program to Procure and Deploy Advanced Radiation Detection Portal Monitors Is Likely to Exceed the Department's Previous Cost Estimates.” September 22, 2008.

GAO-08-1178T: "Combating Nuclear Smuggling: DHS Needs to Consider the Full Costs and Complete All Tests Prior to making a Decision on Whether to Purchase Advanced Portal Monitors.” September 25, 2008.

GAO-09-257: "Nuclear Detection: Domestic Nuclear Detection Office Should Improve Planning to Better Address Gaps and Vulnerabilities.” January 2009.

GAO-13-256: “Combating Nuclear Smuggling: Lessons Learned from Cancelled Radiation Portal Monitor Program Could Help Future Acquisitions.” May 2013. 